\title{
EFFECT OF CADMIUM STRESS ON THE POLYPHENOL CONTENT, MORPHOLOGICAL, PHYSIOLOGICAL, AND ANATOMICAL PARAMETERS OF COMMON BEAN (PHASEOLUS VULGARIS L.)
}

\author{
Benhabiles Ait El Hocine, K. ${ }^{1,2 *}$ - Bellout, Y. $^{1}-$ AmGHAR, F. ${ }^{1,2}$ \\ ${ }^{I}$ Department of Biology, Faculty of Sciences, University Mhamad Bougara, Boumerdes, Algeria \\ ${ }^{2}$ Laboratory of Biodiversity, Biotechnology, Environment and Sustainable Development, \\ University Mhamad Bougara, Boumerdes, Algeria \\ *Corresponding author \\ e-mail: k.benhabiles@univ-boumerdes.dz; phone: +213-671-172-603; fax: +213-24-799-012
}

(Received $9^{\text {th }}$ Dec 2019; accepted 24 $4^{\text {th }}$ Mar 2020)

\begin{abstract}
Cadmium (Cd) is one of the most notable heavy metals because of its high mobility and toxicity towards plants. In the present study, we aimed to evaluate the effect of cadmium on growth, physiological parameters, anatomical changes and phenolic compounds content in Phaseolus vulgaris L plant. Seedlings were exposed to cadmium at $0.25 ; 0.5$ and 1 g. $1^{-1}$ for 21 days. Results indicated that cadmium significantly decreased percent seed germination, embryonic radical elongation, plant dry weight, stem/root length and numbers of leaves and lateral roots. Cadmium also induced a decrease in chlorophyll and protein content with all treatments; however, sugar and proline increased significantly with 1 g. $\mathrm{l}^{-1}$. Total phenolic content increased by around $43 \%$ and $32 \%$ in the above ground part and roots respectively. Flavonoids, flavonols, hydrolysable tannins and condensed tannins showed a significant increase with higher cadmium concentration. Cadmium also changed plant root and stem anatomy; a decrease in both number and size of xylem vessels and a delay in xylem differentiation were observed.
\end{abstract}

Keywords: cadmium, Phaseolus vulgaris L., growth, histological changes, phenolic compounds

\section{Introduction}

Modern agro-ecosystems have continually received ever-increasing cadmium $(\mathrm{Cd})$ pollution from several domestic and industrial activities, as well the agricultural application of phosphate fertilizers, sewage sludge and irrigation water contaminated with this element; leading to soil $\mathrm{Cd}$ contamination and increased $\mathrm{Cd}$ uptake by plants grown in those mediums (McLaughlin et al., 2006; Escudey et al., 2007). Cadmium can be found in soils, reaching levels of approximately $1 \mathrm{mg} \cdot \mathrm{kg}^{-1}$ for most of surface soils (Kabata-Pendias, 2000). It is relatively easily available for plant uptake because it is predominantly found in soil solution or bound to solid phase systems (Verbruggen et al., 2009).

In plants, exposure to cadmium induces phytotoxicity symptoms, such as biomass reduction, inhibition of root elongation (Gratao et al., 2009) and causes a reduction of several physiological processes including photosynthesis, respiration and transpiration (Seregin and Ivanov, 2001; He et al., 2017; Yazdi et al., 2019), seed germination (Chugh et al., 1995; Fattahi et al., 2019) and interferes with uptake, transport, and distribution of essential and non-essential mineral elements, especially in the form of $\mathrm{Cd}^{2+}(\mathrm{He}$ et al., 2017). Cd toxicity triggers the over-accumulation of reactive oxygen 
species, ultimately resulting in oxidative stress in plants (Cuypers et al., 2011; Anjum et al., 2015; Gupta et al., 2017)

Antioxidant molecules produced by plants as a response to $\mathrm{Cd}$ uptake, are considered a defense mechanism to metal stress. In this context, many studies have shown the radical scavenging properties of phenols, mainly by yielding electrons (Michalak, 2010; Cruces et al., 2015; Manquián-Cerda et al., 2016). Plants exposed to heavy metal stress have been observed to exude high levels of phenolic compounds (Posmyk et al., 2009; Mongkhonsin et al., 2016; Manquián-Cerda et al., 2018).

The harmful effects of $\mathrm{Cd}$ in soils include also anatomical changes such as variation in root tissues organization, development of apoplastic barriers (Vaculík et al., 2012), structural changes in plant's vascular system (Barcelo et al., 1988).

Common bean (Phaseolus vulgaris L.) is one of the most important grain legumes worldwide; it is a valuable food source for humans around the world and accounts for higher consumption and economic importance. This crop is potentially exposed to $\mathrm{Cd}$ due to a component of fungicide and fertilizer formulations and amendment that is commonly used in agriculture throughout the word.

The purpose of this study was to evaluate $\mathrm{Cd}$ effect on: (i) morphological and physiological parameters, (ii) polyphenol accumulation in seedlings, (iii) root and stem structure in order to obtain detailed picture of $\mathrm{Cd}$-induced structural disorders in vessels. It should help to explain responses of common bean to $\mathrm{Cd}$ stress.

\section{Materials and methods}

\section{Plant material, treatments and growth conditions}

Study was done in Algeria northern Africa under laboratory conditions. Common bean (Phaseolus vugaris L.) Djadida genotype commonly cultivated there was used. Seeds were selected, surface-disinfected using $0.1 \%$ sodium hypochlorite $(\mathrm{NaClO})$ for $10 \mathrm{~min}$, rinsed and soaked in distilled water at room temperature for $12 \mathrm{~h}$. Seeds were then germinated in sealed plastic dishes with moistened filter paper at $25{ }^{\circ} \mathrm{C}$ in dark for 3 days. Uniform seedlings were selected and transplanted to pots containing mould with $16 \mathrm{~h}$ light and $8 \mathrm{~h}$ dark cycle at average day/night temperature of $25{ }^{\circ} \mathrm{C} / 20^{\circ} \mathrm{C}$ and average relative humidity of $75 \%$, watered as needed according to field capacity calculated in gram of water per gram of soil and afterwards, till the end of the experiment for 21 days. The following treatments were considered: (1) $0.25 \mathrm{~g} . \mathrm{l}^{-1} \mathrm{of} \mathrm{Cd}$, (2) $0.5 \mathrm{~g} . \mathrm{l}^{-1}$ of $\mathrm{Cd}$, (3) $1 \mathrm{~g} . \mathrm{l}^{-1}$ of $\mathrm{Cd}$. The $\mathrm{Cd}$ concentration was supplied us $\mathrm{CdCl}_{2}$ water solution. For control experiment, Cd was omitted.

\section{Seed germination and root elongation test}

This test serves to verify the effect of cadmium on seeds germination. After selection and disinfection, seeds were placed in boxes containing filter paper moistened with cadmium solution at different concentrations 0.25 g. $l^{-1}, 0.5$ g. $l^{-1}, 1$ g. $l^{-1}$ and control moistened with distilled water. In each box 50 seeds were putted at $25{ }^{\circ} \mathrm{C}$ temperature in dark, with three repetitions for each concentration. Seeds were watered as needed by distilled water during 7 days.

To calculate the germination rate, we counted seeds sprouted per box every day until the seventh day, knowing that germination is positive when its radical reaches $5 \mathrm{~mm}$ in 
length. After the seventh day of seed germination, radical's length of germinated seeds was measured on $\mathrm{cm}$.

To obtain percentage of germination, we used the formula:

$$
\mathrm{G}(\%)=(\text { number of germinated seeds / total number of seeds }) \times 100
$$

\section{Morphological parameters}

The different studied parameters are: Stem height and root length measured in $\mathrm{cm}$; number of leaves and lateral roots. After sampling, roots were separated from aboveground part of plants and dried at $80{ }^{\circ} \mathrm{C}$ temperature for $48 \mathrm{~h}$ and weighed until we obtained a fixed weight in order to have the dry matter yield per pot.

\section{Determination of tolerance index}

Tolerance index (TI) was calculated as a ratio of the mean dry weight of plants grown in presence of $\mathrm{Cd}$ and mean dry weight of control plants. TI values lower than 1 suggests that plants are stressed due to metal pollution. Whereas, TI values equal to 1 indicate no difference relative to control treatments. Also, TI values higher than 1 indicate that plant is a hyper accumulator (Audet and Charest, 2007).

\section{Biochemical and physiological parameters}

\section{Photosynthetic pigments determination}

For photosynthetic pigments (chlorophyll $a$ and $b$, carotenoids) analysis, fully developed trifoliate leaves were extracted with $80 \%$ acetone. Pigments contents were determined spectrophotometrically (spectrophotometer Shimadzu UV 1800) at following wavelengths: 663, 646 and $470 \mathrm{~nm}$ and calculated according to Lichtenthaler and Wellburn (1983).

\section{Total soluble sugars}

Leaves were used for soluble sugar determination; extraction was done with $80 \%$ (v/v) ethanol. Sugar content of resulting solution was determined following to Dische (1962) using anthrone reagent. Absorbance was measured at $620 \mathrm{~nm}$. Standards of glucose were prepared and analyzed in the same way to obtain a calibration curve. Soluble sugars content was calculated as mg glucose equivalent $\mathrm{g}^{-1} \mathrm{FW}$.

\section{Total protein content}

The protein content in leaf tissue was determined according to Bradford (1976), Fresh leaves were homogenized and extracted with $5 \mathrm{mM}$ buffer Tris-HCl, $\mathrm{pH} 7.2$, $0.25 \mathrm{M}$ sucrose and $1 \mathrm{mM} \mathrm{MgCl}_{2}$. The extract was incubated with Bradford reagent in darkness. Absorbance was measured at $595 \mathrm{~nm}$ and the amount of proteins was expressed in equivalents of BSA bovin serum albumin (mg eq. BSA g ${ }^{-1} \mathrm{FW}$ ), used as standard.

\section{Proline content}

Proline content was determined following to Bates et al. (1973), using ninhydrin reagent. The absorbance was measured at $520 \mathrm{~nm}$. Reference standards of proline were 
prepared and analyzed in the same way to obtain a calibration curve. Results were expressed on $\mu \mathrm{g} . \mathrm{g}^{-1} \mathrm{DW}$.

\section{Estimation of phenolic compounds}

Phenolic compounds were extracted from shoot and roots dried samples of Phaseolus vulgaris $\mathrm{L}$. The amount of total phenolics in the extract was determined using Folin Ciocalteu reagent as described by Meyers et al. (2003). Absorbance was measured at $750 \mathrm{~nm}$ and the results expressed in equivalents of gallic acid (mg eq. GA g ${ }^{-1} \mathrm{DW}$ ), used as standard.

Colorimetric aluminum chloride method was used for flavonoids and flavonols determination, using optimized protocols established by Bahorun et al. (1996); Kumaranand Karunakaran (2007a, b), respectively. Absorbance was measured at 430 and $440 \mathrm{~nm}$ respectively, and the amount of flavonoids and flavonol were expressed in equivalents of Quercetin (mg eq. $\mathrm{Q} \mathrm{g}{ }^{-1} \mathrm{DW}$ ), used as standard.

Hydrolysable tannins content was determined as described by Mole and Waterman (1987) and was quantified according to standard curve prepared for tannic acid. Results were expressed in equivalent of tannic acid (mg eq. $\mathrm{TA} \mathrm{g}^{-1} \mathrm{DW}$ ).

Condensed tannins contents were determined following the method described by Swain and Hillis (1959). The absorbance was measured at $500 \mathrm{~nm}$. The amount of condensed tannins was expressed in equivalents of catéchin (mg eq. $\mathrm{CAg}^{-1} \mathrm{DW}$ ), used as standard.

\section{Anatomical study}

At day 21 from sowing, samples were taken for light microscopy study. Sections were performed on fresh plants. Cross sections were made on the main root $(1 \mathrm{~cm}$ of the collar; area of lateral roots), and those of stem are represented between first and second internodes. Samples were cut with a vibratome in order to obtain $100-\mu \mathrm{m}$ transverse sections; fresh sections were collected and stained with iodine green carmine as described in Locquin and Langeron (1978).

Specimens were analyzed using a light microscope (optika B-350, Italy) using $\times 100$ and $\times 400$ magnifications, light micrographs were acquired by a digital camera and the images were processed and archived with TS view software version 6.2.4.5, tucsen imagin technology.

\section{Statistical analyses}

All data presented are the mean values of tree replicates \pm standard deviation (SD). Statistical analysis was carried out by student analysis at $5 \%, 1 \%$ and $0.1 \%$ significance level, using statistical software package STATISTICA version 8.0

\section{Results}

\section{Effect of Cd on germination and root elongation}

Smaller number of seeds germinated in comparison with control variant was identified when $\mathrm{Cd}$ was added. Percent seeds germination was affected by different cadmium concentrations, it was lowered by about $68 \%$ with 0.25 g. $1^{-1}$ of metal, $84 \%$ with 0.5 g. $\mathrm{l}^{-1}$ and $98 \%$ with 1 g. $1^{-1} \mathrm{Cd}$ concentration $\left(\mathrm{p}<0.05^{*}\right)$ in contrast to control (Fig. 1A). 


$$
\text { - } 3761 \text { - }
$$

However, elongation of embryonic radical was impaired by about 70\%, 87\%, 91\% (Fig. 1B) by $0.25 ; 0.5$ g. $1^{-1}$ and 1 g..$^{-1}$ Cd respectively $\left(\mathrm{p}<0.01^{* *}\right)$ compared to control.

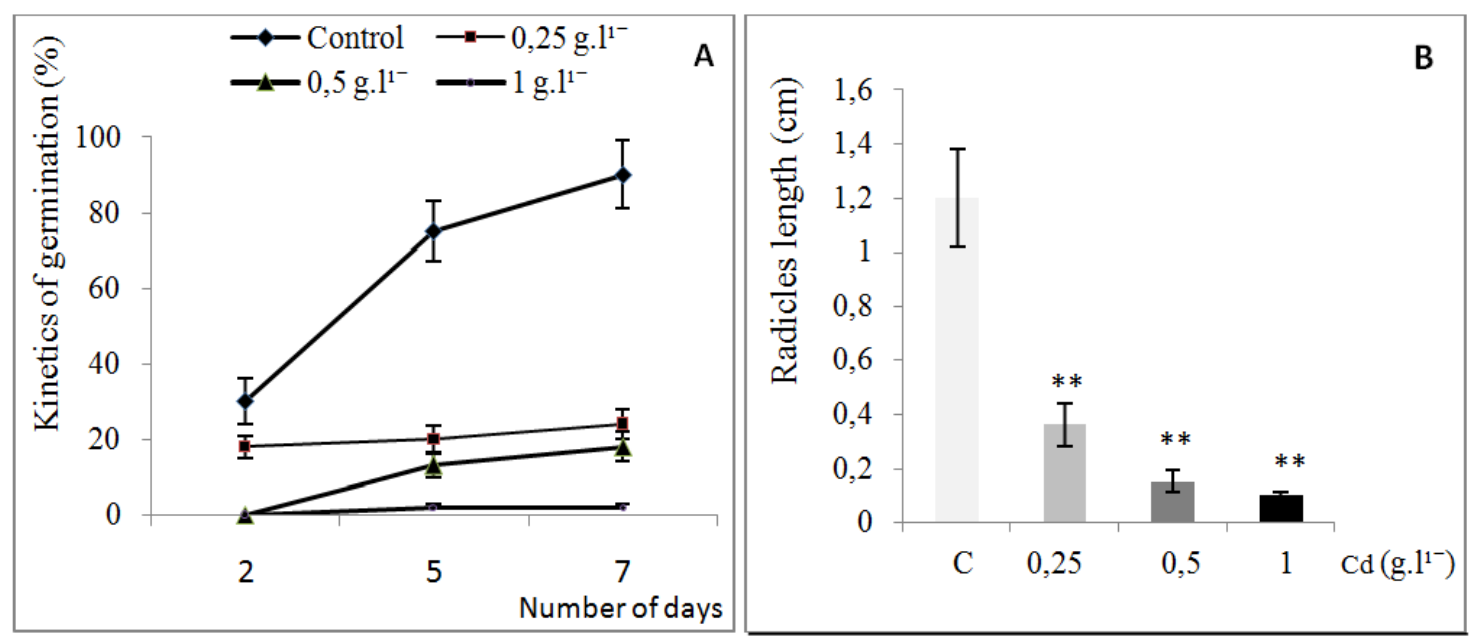

Figure 1. Effects of cadmium $(C d)$ on $(A)$ germination kinetics, $(B)$ radicles length of common bean seeds (Phaseolus vulgaris L.). Results represent the mean $\pm S E(n=3)\left({ }^{*} p<0.05\right.$, $* * p<0.01, * * * p<0.001$ according to Student test)

\section{Effect of Cd on plant growth}

Morphological changes in Phaseolus vulgaris L. plants treated with concentrations of Cd showed leaf chlorosis, growth inhibition; stem weakening and dark brown root tips. We noted that 21-day-old, bean seedlings on polluted soil developed all aerial organs but shorter compared to control plants. Dark brown root tips and reduced growth are the most common physiological effects of heavy metal exposure in plants (Ovečka and Takáč, 2014). Stem and main root length is $68.58 \%$ and $71.43 \%$ shorter respectively in bean plants grown in $1 \mathrm{~g} . \mathrm{l}^{-1} \mathrm{Cd}$ concentration compared with those of controls (Fig. 2A); in this same concentration, bean plants had 50\% fewer leaves and $20 \%$ fewer lateral roots per plant (Fig. 2B). The above ground part-roots dry weight and TI which represent relative plant growth were adversely affected by $\mathrm{Cd}$ concentrations; they decreased gradually with increase of $\mathrm{Cd}$ concentrations. This decrease was around $77.27 \%$ in above ground part length, and $47.97 \%$ in roots length comparing to their respective control under $1 \mathrm{~g}^{-1} \mathrm{l}^{-1} \mathrm{Cd}$ (Fig. 2C). According to results shown in Table 1, Tolerance Index of bean plants is less than 1 for all $\mathrm{Cd}$ concentrations in both part of plant, this confirmed a net decrease in biomass and suggests that Phaseolus vulgaris L. plants are stressed.

Treatment with 0.5 and $1 \mathrm{~g} . \mathrm{l}^{-1}$ of $\mathrm{Cd}$ elicited significant decrease in all growth parameters as compared with control value $(\mathrm{P}<0.05 *)$, except for lateral roots number and roots dry weight; no changes were observed.

Table 1. Value of tolerance index of bean plants according to Cd concentrations

\begin{tabular}{c|c|c|c}
\hline \multicolumn{3}{c}{ Cadmium treatments } \\
\hline TI & $0.25 \mathrm{~g} . \mathrm{l}^{-1} \mathrm{Cd}$ & $0.5 \mathrm{~g} . \mathrm{l}^{-1} \mathrm{Cd}$ & $1 \mathrm{~g} . \mathrm{l}^{-1} \mathrm{Cd}$ \\
Above ground part & 0.65 & 0.34 & 0.22 \\
Roots & 0.82 & 0.58 & 0.52 \\
\hline
\end{tabular}




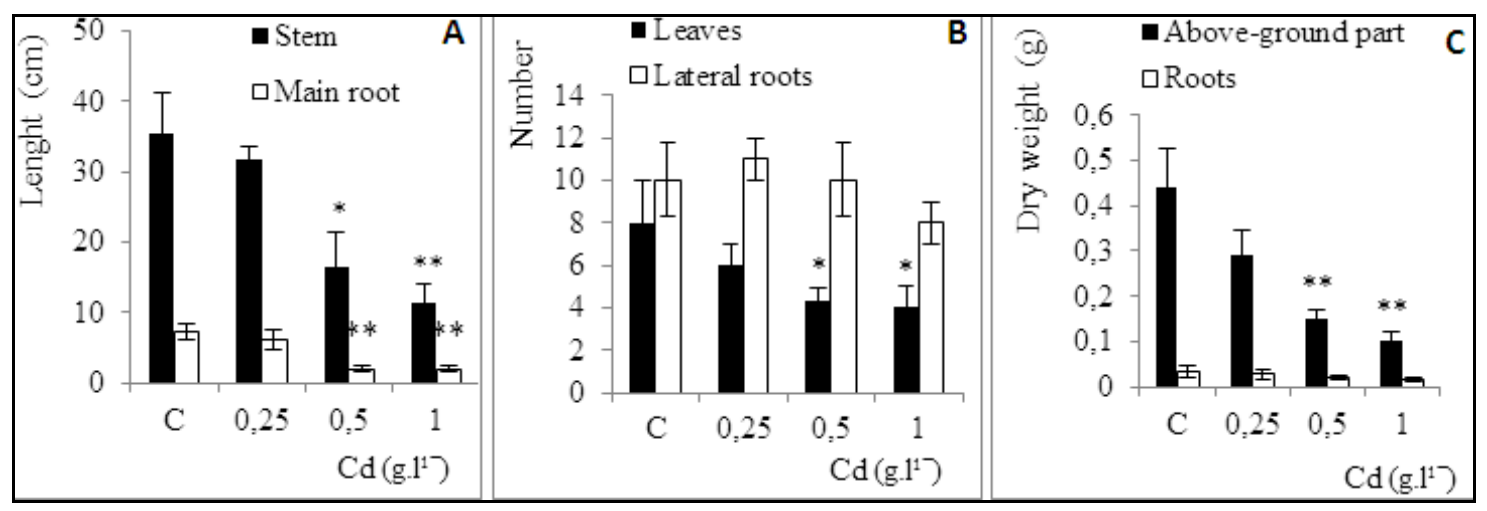

Figure 2. Effects of cadmium $(C d)$ on (A) stem and main root length, $(B)$ leaves and lateral roots number, and $(C)$ dry weight of common bean seedling (Phaseolus vulgaris L.). Results represent mean $\pm S E(n=3)\left({ }^{*} p<0.05, * * p<0.01,{ }^{* * *} p<0.001\right.$ according to Student test $)$

\section{Biochemical and physiological parameters}

$\mathrm{Cd}$ treatment results in decline in chlorophyll content with increasing $\mathrm{Cd}$ concentrations. Chl $a$ decreased significantly $\left(\mathrm{P}<0.01^{* *}\right)$ under all treatments till $56.87 \%$ compared to control. However, $\mathrm{Chl} b$ decrease was significant only under $1{\mathrm{~g} . \mathrm{l}^{-1}}^{-1}$ $\mathrm{Cd}\left(\mathrm{p}<0.05^{*}\right)$ till $31.19 \%$ compared to control (Fig. 3A). When total carotenoids content showed a decrease reaching their lowest value under 1 g. $\mathrm{l}^{-1} \mathrm{Cd}$ treatment $\left(\mathrm{p}<0.05^{*}\right)$ in contrast to control (Fig. 3B).

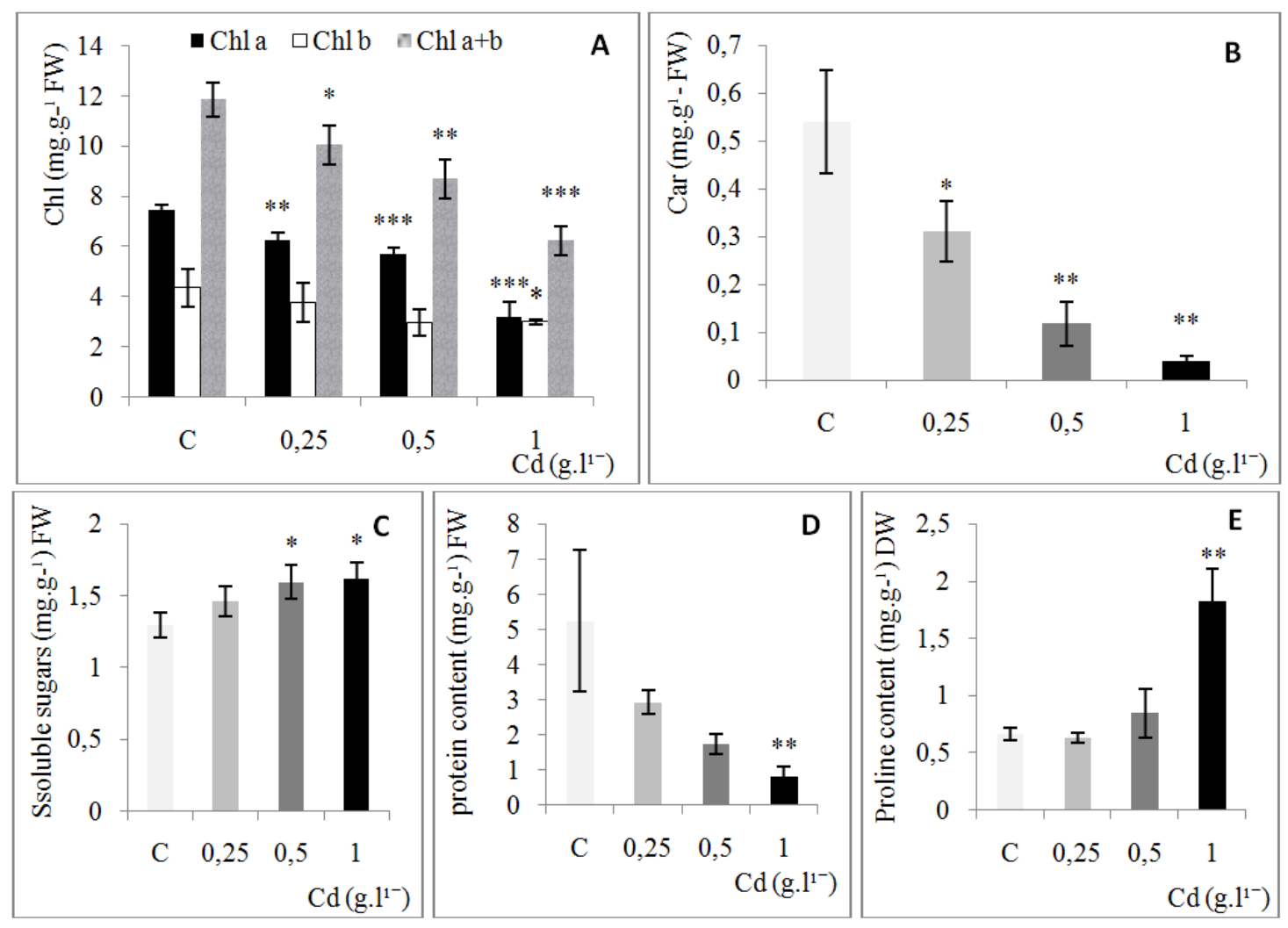

Figure 3. Effects of cadmium $(C d)$ on biochemical parameters of common bean seedling (Phaseolus vulgaris L.). Results represent the mean $\pm S E(n=3)\left({ }^{*} p<0.05,{ }^{* *} p<0.01\right.$, $* * * p<0.001$ according to Student test) 
It is obvious from Figure $3 C$ that total soluble sugars content, appeared to increase

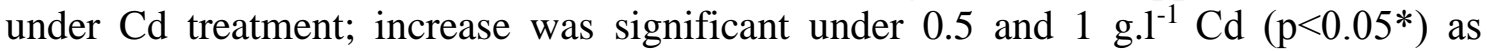
compared with control value, it reached $24.80 \%$.

Bean plants exhibited a significant decrease in proteins content with $1 \mathrm{~g} .1^{-1} \mathrm{Cd}$ concentration $\left(\mathrm{p}<0.01^{* *}\right)$ reaching $84.67 \%$ compared to control (Fig. 3D) when proline appeared to increase progressively with increase of Cd concentrations till $63.80 \%$ with 1 g. $1^{-1}$ Cd concentration $\left(\mathrm{P}<0.01^{*}\right)$ (Fig. 3E).

\section{Changes in phenolic compounds}

Phenolic content in Phaseolus vulgaris L. extract is shown in Figure 4. Increasing levels of $\mathrm{Cd}$ markedly increased synthesis of these metabolites in all treatments in both above ground part and roots $\left(\mathrm{p}<0.05^{*}\right)$ in contrast to control, aside from roots hydrolysable tannins. The rates of increase were till 43, 63, 58, 106, 239\% in above ground part, and till 32, 34, 65, 31 and $20 \%$ in roots for total phenolics, flavonoids, flavonols, hydrolysable tannins and condensed tannins respectively.

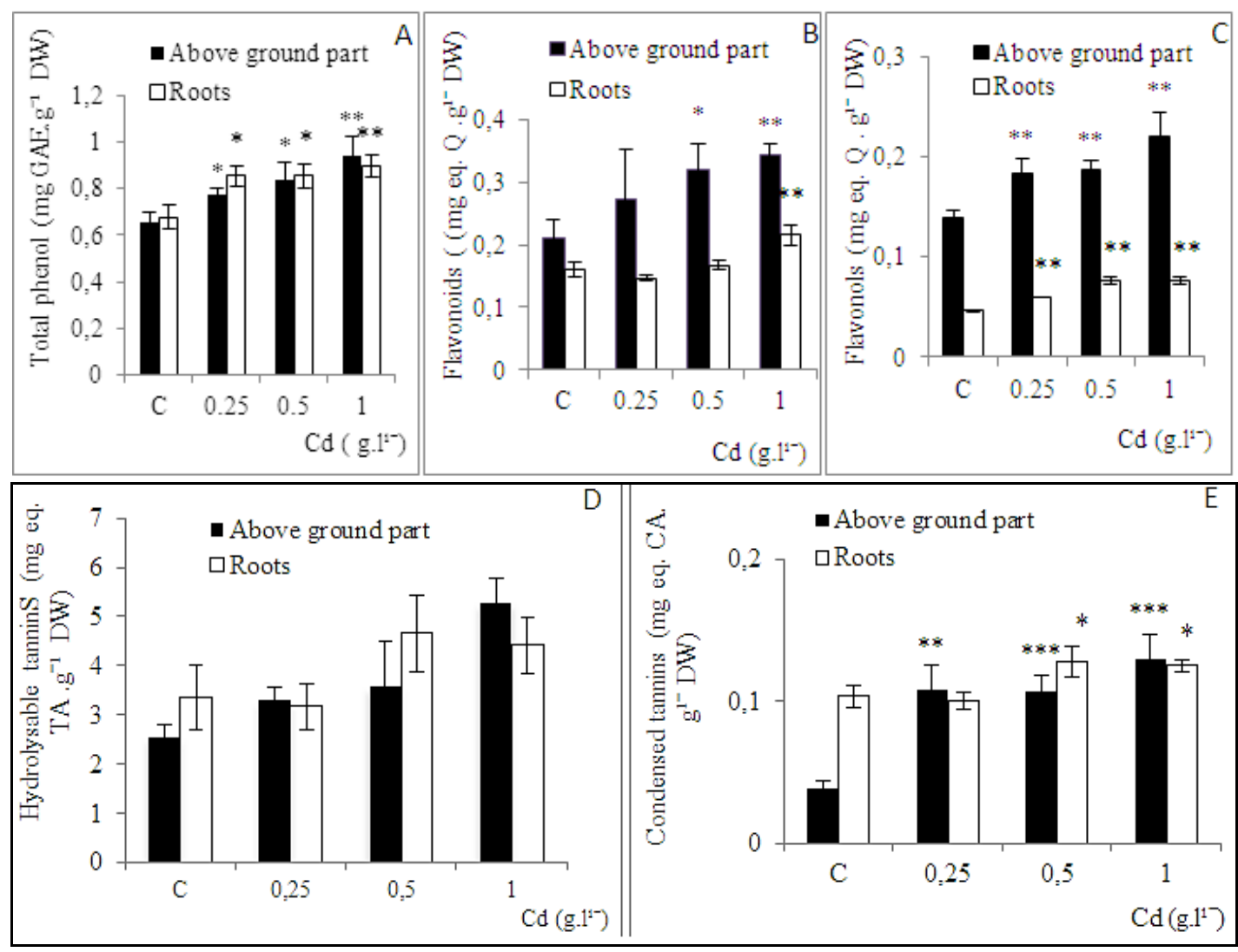

Figure 4. Effects of cadmium $(C d)$ on phenolic compounds content of comman bean seedling (Phaseolus vulgaris L.). Results represent the mean $\pm S E(n=3)\left(* p<0.05\right.$, ${ }^{* *} p<0.01$, $* * * p<0.001$ according to Student test)

\section{Anatomical study}

Our results showed that stem (Fig. 5A, B, C, D) and root (Fig. 6A, B, C, D) diameter sections were similar in control and all $\mathrm{Cd}$ treatment plant samples, with slight flattening of stem section. Cortex cells are similar in size in all samples; however, there 
was a slight enlargement of cortex zone in primary roots and stem that had been exposed to Cd. At high magnification (Figs. 5E, F, G, H, 6E, F, G, H), a decrease of both number and size of xylem vessels in root and stem sections was observed and xylem differentiation appears retarded in plants grown in presence of $\mathrm{Cd}$. which probably led to a decrease in raw sap flow.

Development of plant led to progressive disappearance of cortical parenchyma resulting to medular lacunae formation in plants stem; our results showed that medular lacunae diameter decreased with increase of $\mathrm{Cd}$ concentration till its disappearance with 1 g. $1^{-1} \mathrm{Cd}$ concentration (Fig. 5), which suggests a delay in development of bean plant. In addition, sections showed appearance of secondary tissues in control, in contrast these tissues were retarded in plants grown with $\mathrm{Cd}$ treatment with a high number of cambial cells (Figs. 5E, F, G, H, 6E, F, G, H).

In root, higher $\mathrm{Cd}$ concentrations can result in rhizodermis disintegration in some location of root, but lateral root initiation was observed in all samples (Fig. 6A, B, C, D).
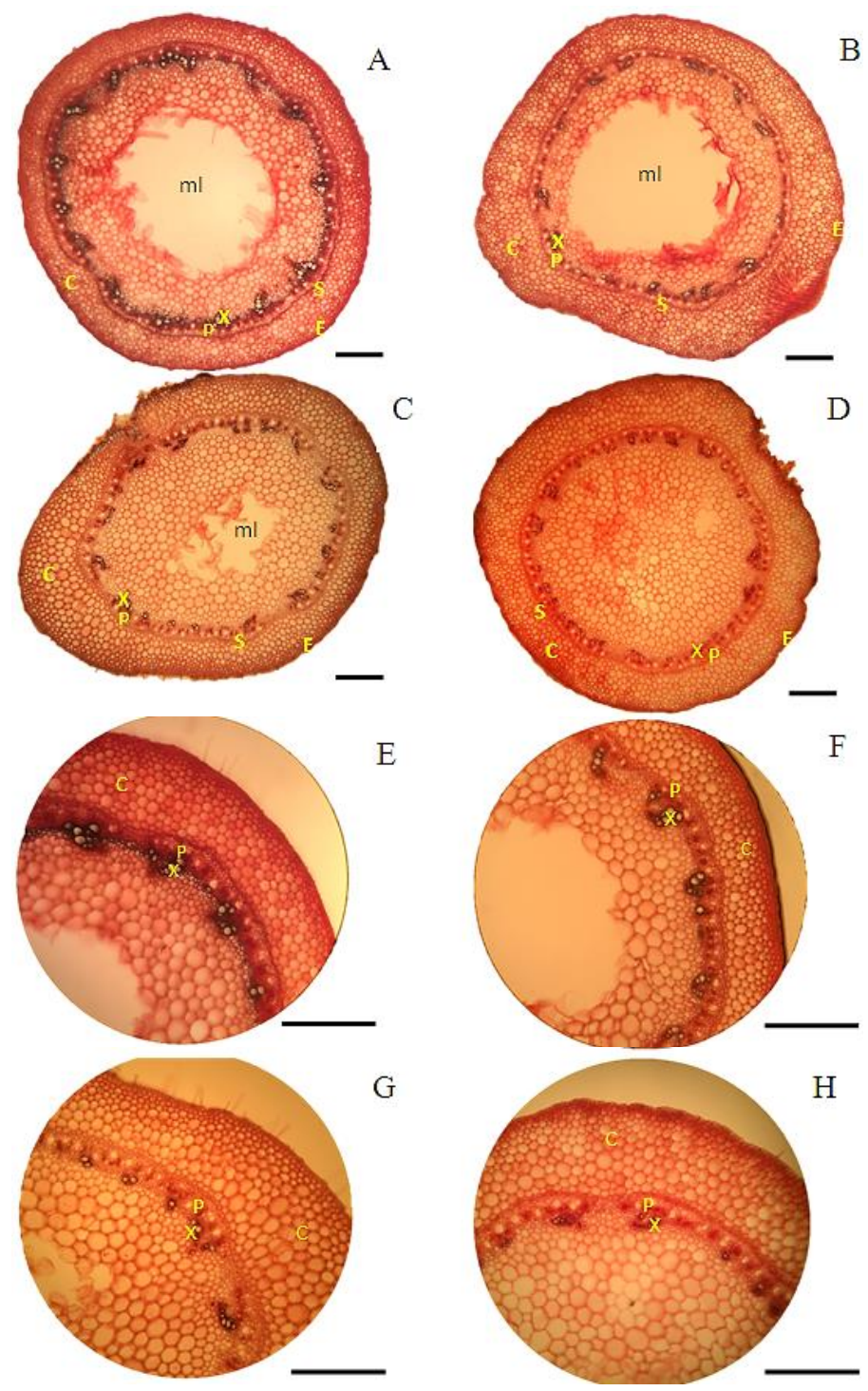

Figure 5. Light micrographs of control $(A, E)$ and Cd-treated plants: $0.25 \mathrm{~g} . \mathrm{l}^{-1}(B, F) ; 0.5 \mathrm{~g} . \mathrm{l}^{-1}$ $(C, G) ; 1$ g. $l^{-1}(D, H)$ showing transversal stem sections. C: cortex, X: xylem, P: phloem, $S$ : sclerenchyma, E: epidermis, ml: medular lacunae; Scale bar, $500 \mu \mathrm{m}$ 


$$
\text { - } 3765-
$$
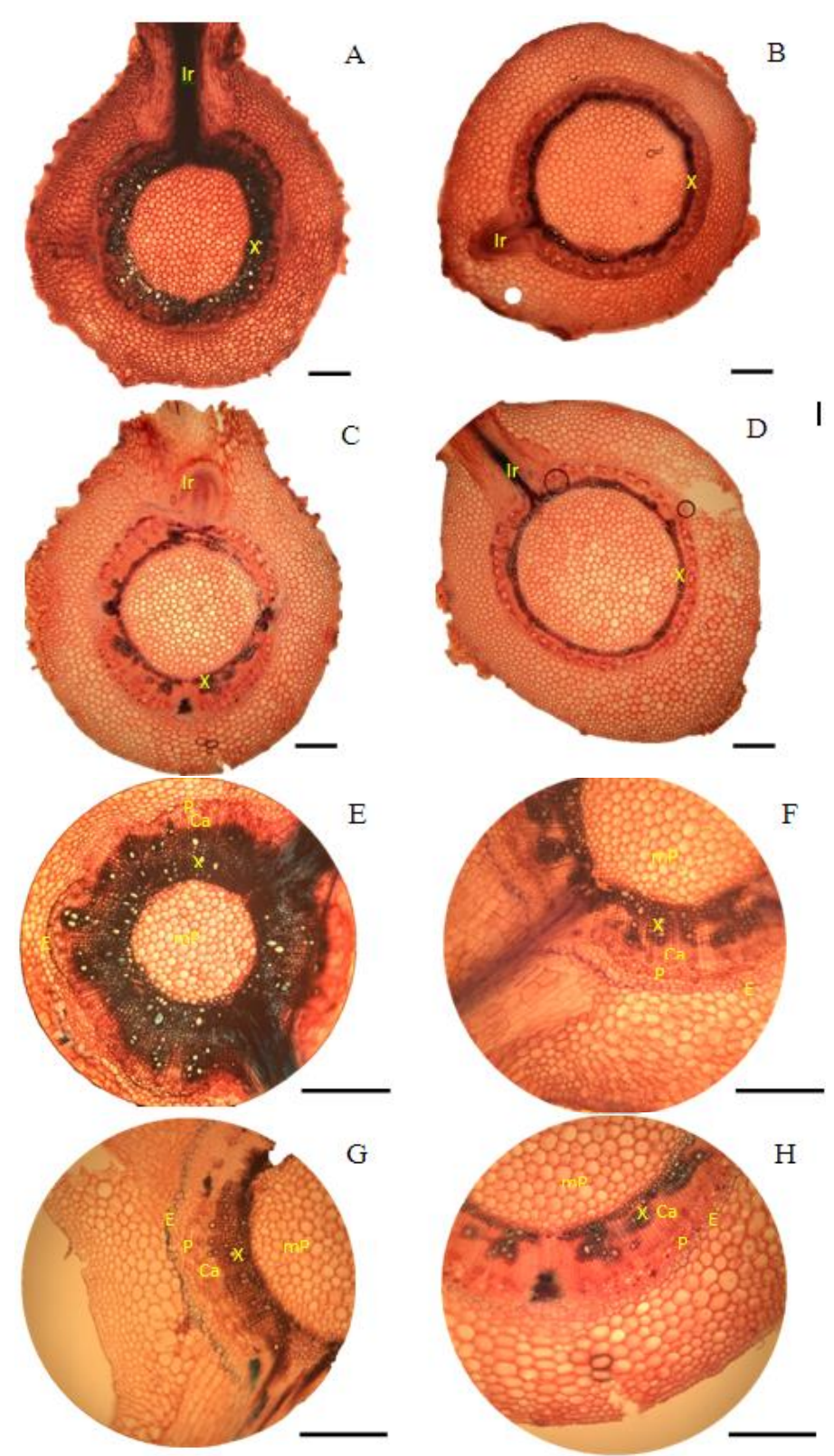

Figure 6. Light micrographs of control $(A, E)$ and Cd-treated plants: 0.25 g. $l^{-1}(B, F) ; 0.5$ g. $l^{-1}(C, G) ; 1$ g. $l^{-1}(D, H)$ showing transversal root sections. C: cortex, X: xylem, P: phloem, E: endodermis, Ca: cambium; lr: lateral root; mP: medular parenchyma; Scale bar, $500 \mu \mathrm{m}$

\section{Discussion}

\section{Effect of Cd on germination and root elongation}

Seed germination and root elongation tests are frequently used for assessing heavy metal phytotoxicity (Wang and Keturi, 1990; Munzuroglu and Geckil, 2002). Our results indicated significant inhibition of seed germination and root elongation under $\mathrm{Cd}$ stress which is in agreement with previous results of Li et al. (2005) on Arabidopsis thaliana. Hsu and Chang-Hung Chou (1992) reported that among heavy metals tested, Cd showed more toxicity to seed germination of Miscanthus, Fattahi et al. (2019) also 
indicated that the increase in $\mathrm{Cd}$ concentrations led to an increase in germination time and a reduction in germination percentage.

According to Kranner and Colville (2011), Cd hamper water uptake inhibiting seed germination, and prolonged their dormancy under room temperature, Munzuroğlu et al. (2008) demonstrate that the inhibition of germination was related with abscisic acid accumulation in seeds. In addition, starch is the most abundant stored material in seeds used in germination after being degraded by enzymes such as amylase; so, inhibition of specific enzymatic reactions by heavy metals causes a negative effect on germination (Ko et al., 2012).

\section{Effect of Cd on plant growth}

Plant growth is one of the best indicators to evaluate plant response to environmental stress. Cadmium stress is a major environmental factor which induces various phytotoxicity symptoms such as stunted growth, root browning, chlorosis, necrosis and cell apoptosis (Chang et al., 2013; Zemanová et al., 2015; Younis et al., 2018a).

Our experimental data revealed that cadmium stress inhibited the growth of bean plants; similar behavior was reported by Yazdi et al. (2019), who found that seedlings of lettuce treated with low doses of $\mathrm{Cd}\left(100,200\right.$, and $300 \mu \mathrm{g} \cdot \mathrm{g}^{-1}$ perlite $)$ had phytotoxic effects. In addition, Younis et al. (2018a) reported that (Phaseolus vulgaris) treated with $\left(10^{-6}, 10^{-3} \mathrm{M} \mathrm{Cd}\right)$ showed a significant decrease in growth parameters. The same result was observed in research conducted on three Miscanthus species (Guo et al., 2016). Growth inhibition could be attributed to inhibiting photosynthesis, respiration, water and nutrient uptake by Cd (Dias et al., 2013; Xue et al., 2013). The production of various forms of reactive oxygen species under inductive oxidative stress due to heavy metals presence, results in retardation of plant growth that could eventually led to plant death (Loi et al., 2018). It has been proposed that inhibition of root and shoot growth in presence of heavy metals may be mainly due to abnormal cell division as well as interference of heavy metals with cofactors that play a vital role in photosynthesis, respiration and protein synthesis in root and shoot of plants (Volland et al., 2014).

\section{Biochemical and physiological parameters}

Cadmium treatments cause a decrease in pigmentation of common bean shoots wich is in accordance with results of Molnarova et al. (2012) on Sinapis alba shoots., Younis et al. (2018a) on P. vulgaris L., Yazdi et al. (2019) on Lactuca sativa Linn. and Chen et al. (2019) on Kandelia obovata.

Decrease in chlorophyll content is attributed to inhibition of chlorophyll synthesis either by affecting key enzymes synthesis such as d-aminolevulinic acid dehydratase (ALA-dehydratase) and proto-chlorophyllide reductase (Stobart et al., 1985; Van Assche and Clijsters,1990), or indirectly by induction of Fe deficiency by inhibiting $\mathrm{Fe}(\mathrm{III})$ reductase and seriously affecting photosynthesis (Alkantara et al., 1994; Lang et al.,1995; He et al., 2017). Cd is also known to enhance chlorophyll enzymatic degradation (Somashekaraiah et al., 1992).

Sugars are involved in many mechanisms of biotic or abiotic stress response, their action in abiotic stress is very wide, they can act as an osmoprotectants by stabilising cellular membranes and maintaining turgor (Peshev and Ende, 2013) or as antioxidant molecules (Keunen et al., 2013). 
Our results indicate that $\mathrm{Cd}$ treatment led to an increase in total soluble sugars content in common bean. Similar results have been reported by Li et al. (2013) on wheat plants and Vezza et al. (2018) on soybean plants under Zn and As stress, respectively. Contrary to these results, reducing sugar content was observed in Phaseolus vulgaris L. under Pb and Cd stress (Bhardwaj et al., 2009; Younis et al., 2018a). In fact, cadmium induced perturbation in metabolism of carbohydrates by modulating their enzymes activities and causes sugar accumulation (Devi et al., 2007; Mishra and Dubey, 2013)

Protein content is inversely proportional to $\mathrm{Cd}$ concentrations, it decreases with $\mathrm{Cd}$ increasing. This is may be due to enhanced protein hydrolysis either by increased protease activity (Palma et al., 2002; Melnichuk et al., 1982) or by fragmentation of proteins due to toxic effects of reactive oxygen species. In fact, denaturant ion of functional and structural proteins is known as a result of reactive oxygen species (ROS) production in cells under stress conditions (Davies et al., 1987; Bowler et al., 1992). Moreover, decrease in protein content can also be attributed to their slowdown biosynthesis due to a decrease in nitrate reductase activity (Fresneau et al., 2007). Similar effects have been showed in several other plant species under Cd stress (Tamas et al., 1997; John et al., 2008; Aslam et al., 2014) or in Phaseolus vulgaris L. Plant (Bhardwaj et al., 2009; Younis et al., 2018a).

Proline has always been considered as a biomarker of drought or salt stress. Actually, several studies associated its accumulation with heavy metal stress (Alia and Pardha, 1991; Choudhary et al., 2007; Vezza et al., 2018; Younis et al., 2018a). Proline promotes photosynthetic activity, water status, antioxidative enzymes activities (Zouari et al., 2016) and assures osmotic adjustment at cellular level (Kasai et al., 1998). According to Alia and Pardha (1991), increase in proline level could be either due to its fresh synthesis and/or due to decrease in its utilization in stressed plants. Li et al. (2013) reported that accumulation of proline is due to ornithine pathway involving in OAT (ornithine d-aminotransferase) stimulation a biosynthesis enzyme of proline; on the other hand, a decrease in GK (glutamate kinase) and PDH (proline dehydrogenase) activities involved in catabolism of proline.

\section{Changes in phenolic compounds}

Oxidative stress is an important mechanism of cadmium toxicity (Smeets et al., 2005). Plants use a complex antioxidant defense system to prevent oxidative damage and keep reactive oxygen species concentrations within a narrow functional range (Ozgur et al., 2013). The primary components of this system include non-enzymatic radical scavengers among them carotenoids, flavonoides, and phenolic compounds. These components keep plant cells away from oxidative damage by scavenging ROS (Schafer et al., 2002). A better understanding of underlying antioxidant mechanisms mediated by phenolic compounds is necessary to develop strategies for contaminated crop soil.

Phaseolus vulgaris L. grown under Cd treatments showed a significant increase of phenolic compounds and total flavonoids contents in both parts of plant. Under heavy metal stress, phenolic compounds can act as transition metal ions chelators, ROS scavengers (Vollmannova et al., 2014; Manquian-Cerda et al., 2016) and can suppress lipid peroxidation by breaking radical chain reactions during lipid peroxidation (Arora et al., 2000; Sakihama and Yamasaki, 2002).

Chen et al. (2019) reported that the activity of Shikimate dehydrogenase (SKDH), cinnamyl alcohol dehydrogenase (CAD), and polyphenol oxidase (PPO) increased at the 
meantime when total phenolic compounds increase in Kandelia obovata exposed to higher concentrations of cadmium ( $\mathrm{Cd}$ ) and zinc ( $\mathrm{Zn})$, which indicate that $\mathrm{Cd}$ and $\mathrm{Zn}$ play a previously unrecognized but major role in phenolic compounds synthesis, transport, and metabolism. Kovácik et al. (2006) affirmed that activation of the phenylalanine ammonia-Liaza (PAL) enzyme is the main cause of increase in the phenolic metabolits concentration, since it is the main biosynthetic pathway of phenolic compounds. Increase of total phenolic compounds under $\mathrm{Cd}$ pollution has been reported in several plants, including $P$. vulgaris (Manquian-Cerda et al., 2016; Mongkhonsin et al., 2016; Younis et al., 2018b; Chen et al., 2019).

Flavonoids are frequently induced by abiotic stress especially by heavy metals and promote roles in plant protection (Grace and Logan, 2000; Dai et al., 2006). Biological and antioxidant activities of flavonols, among others quercetin, have been proven (Tsai et al., 2002). Posmyk et al. (2009) reported that at $0.5 \mathrm{mM} \mathrm{Cu}^{2+}$ stress, anthocyanins concentration increased and that anthocyanins synthesis was the effective strategy against ROS generated by $\mathrm{Cu}^{2+}$ stress. Flavonoids are known that are inhibitors of lipoxygenase enzyme, which converts polyunsaturated fatty acids to oxygen-containing derivatives (Nijveldt et al., 2001).

Posmyk et al. (2009), Mongkhonsin et al. (2016) and Younis et al. (2018b) examined common bean plant treated with metals such as $\mathrm{Cu}$ and $\mathrm{Cd}$, and reported an increase in flavonoids concentration in both shoots and roots.

In the present study, Cd led to a marked increase of tannins. Tannins have great antioxidant capacities due to their phenol nuclei. According to Bruneton (1999), hydrolysable tannins are ROS and superoxide anion scavengers and are very good proton donors to ROS produced during peroxidation, resulting in more stable tannic radical formation. Tannins are known to remove heavy metals from solutions using green technology (Sun et al., 2019). Oo (2009) reported that the metal ions could interact with hydroxyl groups of mangrove tannins through an ion exchange and/or complexation process.

\section{Anatomical changes}

Plant anatomy is known to be sensitive to physical and chemical conditions, like $\mathrm{Cd}$ pollution area. Anatomical changes in response to $\mathrm{Cd}$ have been long reported (Barcelo et al., 1988; Lux et al., 2011; Pereira et al., 2018) on Phaseolus vulgaris, Zea mays L. and, Solidago chilensis respectively.

Presence of $\mathrm{Cd}$ in soil causes a decrease of both number and size of xylem vessels and a slight enlargement of cortex zone. As mentioned by Maksimovic et al. (2007), the enlargement of cortical tissues had a functional role by decreasing radial flows of water and solutes showed in maize with $\mathrm{Cd}$ and $\mathrm{Ni}$ pollution. Little information is available on development of central cylinder cells and tissues under Cd stress; this topic requires more attention, especially considering the importance of xylem translocation in regulating cadmium movement from roots to aerial tissues (Lux et al., 2011).

Our result were in accord with Aloni (1987), Barcelo et al. (1988) and Vazquez et al. (1992) who reported that $\mathrm{Cd}$ reduces cell division and differentiation in vascular cylinder of Cd-treated bean plants, which seems essential for both production of cambium and cambium cells differentiation into vessels and fibers leading to poor development of vascular bundles. Moreover, the differentiation of cambium to these conducting elements depends on phytohormones like auxins and cytokinins (Aloni, 1987; Bhalerao et Bennett, 2003). Lower auxin concentrations, result in slower differentiation and therefore fewer 
vessels (Aloni, 1988). It seems that Cd stimulates Auxin degradation (Chaoui et al., 2005). Cytokinins seem crucial for formation and maintenance of cambial cells (Fukuda, 2004), furthermore Cd may decrease cambium size and fiber differentiation in stems by inhibiting cytokinin export from roots (Aloni, 1982).

$\mathrm{Cd}$ exposure had not any effect on diameters of bean roots, which is in concordance with Vázquez et al. (1992). However, higher $\mathrm{Cd}$ concentrations can result in rhizodermis disintegration in some location of root, similar abnormal effects have been also described in tomato (Gratão et al., 2009).

\section{Conclusion}

The present study showed clearly that $\mathrm{Cd}$ had negative impact on seed germination, plant growth and caused several physiological and biochemical modifications in Phaseolus vulgaris L. Furthermore, it resulted in noticeable effects on phenolic compounds contents as antioxidant response to $\mathrm{Cd}$. It is supposed that the revealed anatomical changes in xylem under $\mathrm{Cd}$ impact hamper fluid movement from root to shoot and are one of the reasons of nutrients decrease and pollutants translocation from roots to shoots. It might be a tolerance to abiotic stress limiting $\mathrm{Cd}$ impact on plant.

For future studies, evaluation of $\mathrm{Cd}$ effect on phenolic compounds profile and nonenzymatic antioxidants seems to be important.

\section{REFERENCES}

[1] Alia, P., Pardha, S. (1991): Proline accumulation under heavy metal stress. - Journal of Plant Physiology 138: 554-558.

[2] Alkantara, E., Romerza, F. J., Canett, M., De LaGuardia, M. D. (1994): Effect of heavy metals on both induction and function of root $\mathrm{Fe}$ (III) reductase in Fe-deficient cucumber (Cucumis sativus L.). plants. - J. Exp. Bot. 45: 1893-1898.

[3] Aloni, R. (1982): Role of cytokinin in differentiation of secondary xylem fibers. - Plant Physio. 70: 1631-1633.

[4] Aloni, R. (1987): Differentiation of vascular tissues. - Ann. Rev. Plant Physio. 38: 179-204.

[5] Aloni, R. (1988): Vascular Differentiation of within Plants. - In: Roberts, L. W., Mahan, P. B., Aloni, R. (eds.) Vascular Differentiation and Plant Growth Regulators. Springer-Verlag, Berlin, pp. 39-59.

[6] Anjum, S. A., Tanveer, M., Hussain, S., Bao, M., Wang, L., Khan, I., Shahzad, B. (2015) Cadmium toxicity in Maize (Zea mays L.): consequences on antioxidative systems, reactive oxygen species and cadmium accumulation. - Environ SciPollut Res 22: 17022-17030.

[7] Arora, A., Byrem, T. M., Nair, M. G., Strasburg, G. M. (2000): Modulation of liposomal membrane fluidity by flavonoids and isoflavonoids. - Archives of Biochemistry and Biophysics 373: 102-109.

[8] Aslam, R., Ansari, M. Y. K., Choudhary, S., Bhat, T. M., Jahan, N. (2014): Genotoxic effects of heavy metal cadmium on growth, biochemical, cyto-physiological parameters and detection of DNA polymorphism by RAPD in Capsicum annuum L. - an important spice crop of India. - Saudi Journal of Biological Sciences 21: 465-472.

[9] Audet, P., Charest, C. (2007): Heavy metal phytoremediation from a meta-analytical perspective. - Environ. Pollut. 147: 2337.

[10] Bahorun, T., Gressier, B., Trotin, F., Brunet, C., Dine, T., Luyckx, M., Vasseur, J., Cazin, M., Cazin, J. C., Pinkas, M. (1996): Oxygen species scavenging activity of phenolic extracts from hawthorn fresh plant organs and pharmaceutical preparations. - Arzneim Forsch 46: 1086-1108. 
[11] Barcelo, J., Vazquez, M. D., Poschenrieder, C. (1988): Structural and ultrastructural disorders in cadmium-treated bush bean plants (Phaseolus vulgaris L.). - New Phytol 108: 37-49.

[12] Bates, L. S., Waldren, R. P., Teare, I. D. (1973): Rapid determination of free proline for water stress studies. - Plant Soil 39: 205-207.

[13] Bhalerao, R., Bennett, M. (2003): The case for morphogens in plants. - Nature Cell Biology 5: 939-943.

[14] Bhardwaj, P., Chaturvedi, A. K., Prasad, P. (2009): Effect of enhanced lead and cadmium in soil on physiological and biochemical attributes of Phaseolus vulgaris L. - Nat. Sci 7: 63-75.

[15] Bowler, C., Van Montagu, M., Inze, D. (1992): Superoxide dismutase and stress tolerance. - Annu. Rev. Plant Physiol. Plant Mol. Biol. 43: 83-116.

[16] Bradford, M. M. (1976): A rapid and sensitive method for the quantitation of microgram quantities of protein utilizing the principle of protein-dye binding. - Anal. Biochem 72: 248-254.

[17] Bruneton, J. (1999): Pharmacognosie, phytochimie, plantes médcinales. - Thechnique et Documentation. Ed. Lavoisier., Paris, pp. 227-401.

[18] Chang, Y. S., Chang, Y. J., Lin, C. T., Lee, M. C., Wu, C. W., Lai, Y. H. (2013): Nitrogen fertilization promotes the phytoremediation of cadmium in Pentas lanceolata. - Int Biodeter Blodegr. 85: 709-714.

[19] Chaoui, A., El Ferjani, E. (2005): Effects of cadmium and copper on antioxidant capacities, lignification and auxin degradation in leaves of pea (Pisum sativum L.) seedlings. - C R Biol. 328: 23-31.

[20] Chen, S., Wang, Q., Lu, H., Li, J., Yang, D., Liu, J., Yan, C. (2019): Phenolic metabolism and related heavy metal tolerance mechanism in Kandelia obovata under $\mathrm{Cd}$ and $\mathrm{Zn}$ stress. - Ecotoxicology and Environmental Safety 169: 134-143.

[21] Choudhary, M., Jetley, U. K., Abash, M., Zutshi, K. S., Fatma, T. (2007): Effect of heavy metal stress on proline, malondialdehyde, and superoxide dismutase activity in the cyanobacterium spirulina platensis-S5. - Ecotoxicology and Environmental Safety 66: 204209.

[22] Chugh, L. K., Sawhney, S. K. (1995): Effect of cadmium on germination, amylases and rate of respiration of germinating pea seeds. - Environmental Pollution 92: 1-5.

[23] Cruces, E., Rojas-Lillo, Y., Ramirez-Kushel, E., Atala, E., López-Alarcón, C., Lissi, E., Gómez, I. (2015): Comparison of different techniques for the preservation and extraction of phlorotannins in the kelp Lessonia spicata (Phaeophyceae): assays of DPPH, ORAC-PGR, and ORAC-FLas testing methods. - J. Appl. Phycol. 28: 573-580.

[24] Cuypers, A., Smeets, K., Ruytinx, J., Opdenakker, K., Keunen, E., Remans, T., Horemans, N., Vanhoudt, N., Van Sanden, S., Van Belleghem, F. (2011): The cellular redox state as a modulator in cadmium and copper responses in Arabidopsis thaliana seedlings. - J. Plant Physiol 168: 309-316.

[25] Dai, L. P., Xiong, Z. T., Huang, Y., Li, M. J. (2006): Cadmium-induced changes in pigments, total phenolics, and phenylalanine ammonialyase activity in fronds of Azolla imbricate. - Environ. Toxicol. 21: 505-512.

[26] Davies, C. S., Nielsen, S. S., Nielsen, N. C. (1987): Flavor improvement of soybean preparations by genetic removal of lipoxygenase-2. - J. Am. Oil Chem. Soc 64: 1428-1433.

[27] Devi, R., Munjral, N., Gupta, A. K., Kaur, N. (2007): Cadmium induced changes in carbohydrate status and enzymes of carbohydrate metabolism, glycolysis and pentose phosphate pathway in pea. - Environ. Exp. Bot. 61: 167-174.

[28] Dias, M. C., Monteiro, C., Moutinho-Pereira, J., Correia, C., Gonçalves, B., Santos, C. (2013): Cadmium toxicity affects photosynthesis and plant growth at different levels. ActaPhysiol Plant 35: 1281-1289.

[29] Dische, Z. (1962): Color Reactions of Hexoses. - In: Whistler, R. L., Wolfrom, M. L. (eds.) Methods in Carbohydrate Chemistry. Vol. 1. Academic Press, New York, pp. 488-490. 
[30] Escudey, M., Forster, J. E., Becerra, J. P., Quinteros, M., Torres, J., Arancibia, N., Galindo, G., Chang., A. C. (2007): Disposal of domestic sludge and sludge ash on volcanic soils. - J. Hazard. Mater. 139: 550-555.

[31] Fattahi, B., Arzani, K., Souri, M. K., Barzegar, M. (2019): Effects of cadmium and lead on seed germination, morphological traits, and essential oil composition of sweet basil (Ocimum basilicum L.). - Industrial Crops \& Products 138: 111584.

[32] Fresneau, C., Ghashghaie, J., Cornic, G. (2007): Drought effect on nitrate reductase and sucrose phosphate synthase activities in wheat (Triticum durum L.): role of leaf internal CO2. - Journal of Experimental Botany 58: 2983-2992.

[33] Fukuda, H. (2004): Signals that control plant vascular cell differentiation. - Nature Reviews Molecular Cell Biology 5: 379-391.

[34] Grace, S. C., Logan, B. A. (2000): Energy dissipation and radical scavenging by the plant phenyl propanoid pathway. - Philosophical Transactions of the Royal Society B 355: 149510.

[35] Gratao. P. L., Monteiro, C. C., Rossi. M. L., Martinelli, A. P., Peres, L. E. P., Medici, L. O., Lea, P. J., Azevedo, R. A. (2009): Differential ultrastructural changes in tomato hormonal mutants exposed to cadmium. - Environ Exp Bot 67: 387-394.

[36] Guo, H., Hong, C., Chen, X., Xu, Y., Liu, Y., Jiang, D. (2016): Different growth and physiological responses to cadmium of the three Miscanthus species. - PLoS One 11: 0153475.

[37] Gupta, D. K., Pena, L. B., Romero-Puertas, M. C., Hernández, A., Inouhe, M., Sandalio, L. M. (2017): NADPH oxidases differentially regulate ROS metabolism and nutrient uptake under cadmium toxicity. - Plant Cell Environ 40: 509-526.

[38] He, S. Y., Yang, X. E., He, Z., Baligar, V. C. (2017): Morphological and physiological responses of plants to cadmium toxicity: a review. - Pedosphere 27: 421-438.

[39] Hsu, F. H., Chang-Hung Chou (1992): Inhibitory effects of heavy metals on seed germination and seedling growth of Miscanthus species. - Bot. Bull. Acad. Sin. 33: 3342.

[40] John, R., Ahmad, P., Gadgil, K., Sharma, S. (2008): Effect of cadmium and lead on growth, biochemical parameters and uptake in Lemna polyrrhiza L. - Plant Soil Environ. 54: 262270.

[41] Kabata-Pendias, A. (2000): Trace Elements in Soils and Plants. $3^{\text {rd }}$ Ed. - CRC Press, Boca Raton.

[42] Kasai, Y., Kato, M., Aoyama, J., Hyodo, H. (1998): Ethylene production and increase in 1 aminocyclopropane-1 carboxylate oxidase activity during senescence of broccoli florets. Acta Horticulturae 464: 153-157.

[43] Keunen, E., Peshev, D., Van gronsveld, J., Van den ende, W. (2013): Plant sugars are crucial players in the oxidative challenge during abiotic stress: extending the traditional concept. - Plant, Cell \& Environment 36: 1242-1255.

[44] Ko, K. S., Lee, P. K., Kong, I. C. (2012): Evaluation of the toxic effects of arsenite, chromate, cadmium, and copper using a battery of four bioassays. - Appl Microbiol Biotechnol 95: 1343-1350.

[45] Kovcik, J., Tomko, J., Backor, M., Repcak, M. (2006): Matricaria chamomilla is not a hyperaccumulator, but tolerant to cadmium stress. - Plant Growth Regul 50: 239-247.

[46] Kranner, I., Colville, L. (2011): Metals and seeds: biochemical and molecular implications and their significance for seed germination. - Environ. Exp. Bot. 72: 93-105.

[47] Kumaran, A., Karunakaran, R. J. (2007a): Activity-guided isolation and identification of free radical-scavenging components from an aqueous extract of Coleus aromaticus. - Food Chemistry 100: 356-361.

[48] Kumaran, A., Karunakaran, R. J. (2007b): In vitro antioxidant activities of methanol extracts of Phyllanhtus species from India. - Lebens-Wiss Technol 40: 344-352.

[49] Lang, F., Sarvari, E., Szigeti, Z., Fodor, F., Cseh, E. (1995): Effects of Heavy Metals on the Photosynthetic Apparatus in Cucumber. - In: Mathis, P. (ed.), Photosynthesis: From Light to Biosphere. Kluwer Academic Publishers, Dordrecht, pp. 533-536. 
[50] Li, W., Khan, M. A., Yamaguchi, S., Kamiya, Y. (2005): Effects of heavy metals on seed germination and early seedling growth of Arabidopsis thaliana. - Plant Growth Regulation 46: $45-50$.

[51] Li, X., Yang, Y., Jia, L., Chen, H., Wei, X. (2013): Zinc-induced oxidative damage, antioxidant enzyme response and proline metabolism in roots and leaves of wheat plants. Ecotoxicol. Environ. Saf. 89: 150-157.

[52] Lichtenthaler, H. K., Wellburn, A. R. (1983): Determinations of total carotenoids and chlorophylls $a$ and $b$ of leaf extracts in different solvents. - Biochem Society Transactions 11: 591-592.

[53] Locquin, M., Langeron, M. (1978): Manuel de microscopie. - Ed. Masson, France.

[54] Loi, N. N., Sanzharova, N. I., Shchagina, N. I., Mironova, M. P. (2018): The effect of cadmium toxicity on the development of lettuce plants on contaminated sod-podzolic soil. Russ. Agric. Sci. 44: 49-52.

[55] Lux, A., Martinka, M., Vaculık, M., White, P. J. (2011): Root responses to cadmium in the rhizosphere: a review. - J. Exp. Bot. 62: 21-37.

[56] Maksimovic, I., Kastori, R., Krstic, L., Lukovic, J. (2007): Steady presence of cadmium and nickel affects root anatomy, accumulation and distribution of essential ions in maize seedlings. - Biologia Plantarum 51: 589-592.

[57] Manquián-Cerda, K., Escudey, M., Zúñiga, G., Arancibia-Miranda, N., Molina, M., Cruces, E. (2016): Effect of cadmium on phenolic compounds, antioxidant enzyme activity and oxidative stress in blueberry (Vaccinium corymbosum L.) plantlets grown in vitro. Ecotoxicol. Environ. Saf. 133: 316-326.

[58] Manquián-Cerda, K., Cruces, E., Escudey, C., Zúñiga, G., Calderon, R. (2018): Interactive effects of aluminum and cadmium on phenolic compounds, antioxidant enzyme activity and oxidative stress in blueberry (Vaccinium corymbosum L.) plantlets cultivated in vitro. Ecotoxicology and Environmental Safety 150: 320-326.

[59] McLaughlin, M. J., Whatmuff, M., Warne, M., Heemsbergen, D., Barry, G., Bell, M., Nash, D., Pritchardet, D. (2006): A field investigation of solubility and food chain accumulation of biosolid-cadmium across diverse soil types. - Environ Chem: 3428-432.

[60] Melnichuk Yu, P., Lishko, A. K., Kalinin, F. L. (1982): Cd effect on free amino acid content in germs of pea seeds at early germination stages. - Fiziologiya biokhimiya kulturnyh Rasstenii 14: 383-385.

[61] Meyers, K. J., Watkins, C. B., Pritts, M. P., Liu, R. H. (2003): Antioxydant and antiproliferative activities of strawberries. - Journal of Agricultural and Food Chemistry 51: 6887-6892.

[62] Michalak, A., 2010. Phenolic compounds and their antioxidant activity in plants growing under heavy metal stress. - Pol. J. Environ. Stud.15: 523-530.

[63] Mishra, P., Dubey, R. S. (2013): Excess nickel modulates activities of carbohydrate metabolizing enzymes and induces accumulation of sugars by up regulating acid invertase and sucrose synthase in rice seedlings. - Biometals 26: 97-111.

[64] Mole, S., Waterman, P. G. (1987): A critical analysis of techniques for measuring tannins in ecological studies. II. Techniques for biochemically defining tannins. - Oecologia 72: 148156.

[65] Molnarova, M., Fargasova, A. (2012): Relationship between various physiological and biochemical parameters activated by cadmium in Sinapisalba L. and Hordeum vulgare L. Ecological Engineering 49: 62.

[66] Mongkhonsin, B., Nakbanpote, W., Hokura, A., Nuengchamnon, N., Maneechai, S. (2016): Phenolic compounds responding to zinc and/or cadmium treatments in Gynura pseudochina (L.) DC. Extracts and biomass. - Plant Physiol. Biochem. 109: 549-560.

[67] Munzuroglu, O., Geckil, H. (2002): Effects of metals on seed germination, root elongation, and coleoptile and hypocotyl growth in Triticuma estivum and Cucumis sativus. - Bull. Environ. Contam. Toxicol. 43: 203-213. 
[68] Munzuroğlu, O., Zengin, F. K., Yahyagil, Z. (2008): The abscisic acid levels of wheat (Triticuma estivum L. Cv. Cakmak 79) seeds that were germinated under heavy metal $\left(\mathrm{Hg}^{++}, \mathrm{Cd}^{++}, \mathrm{Cu}^{++}\right)$stress. - J. Fac. Pharm. Gazi. 21: 1-7.

[69] Nijveldt, R. J., Van Nood, E., Van Hoorn, D. E. C., Boelens, P. G., Van Norren, K., Van Leeuwen, P. A. M. (2001): Flavonoids: a review of probable mechanisms of action and potential applications. - American Society for Nutrition 74: 418-425.

[70] Oo, C. W., Kassima, M. J., Pizzib, A. (2009): Characterization and performance of Rhizophora apiculata mangrove polyflavonoid tannins in the adsorption of copper (II) and lead (II). - Industrial Crops and Products 30: 152-161.

[71] Ovecka, M., Takac, T. (2014): Managing heavy metal toxicity stress in plants: biological and biotechnological tools. - Biotechnol. Adv. 32: 73-86.

[72] Ozgur, R., Uzilday, B., Sekmen, A. H., Turkan, I. (2013): Reactive oxygen species regulation and antioxidant defence in halophytes. - Functional Plant Biology 40: 832-847.

[73] Palma, J. M., Sandalio, L. M., Javier Corpas, F., Romero-Puertas, M. C., McCarthy, I., del Rio, L. A. (2002): Plant proteases protein degradation and oxidative stress: role of peroxisomes. - Plant Physiol. Biochem 40: 521-530.

[74] Pereira, L. S., Pereira de Araújob, R., Souza de Oliveirac, P., Dias da Silvac, L., CasaesAlvesa, P. A., Fernandesd, V. F., Gross, E. (2018): Cadmium induced changes in Solidago chilensis Meyen (Asteraceae) grown on organically fertilized soil with reference to mycorrhizae, metabolism, anatomy and ultrastructure. - Ecotoxicology and Environmental Safety 150: 75 .

[75] Peshev, D., Van den Ende, W. (2013): Sugars as Antioxidants in Plants. - In: Tuteja, N., Gill, S. S. (eds.) Crop Improvement under Adverse Conditions. Springer-Verlag, Berlin.

[76] Posmyk, M. M., Kontek, R., Janas, K. M. (2009) Antioxidant enzymes activity and phenolic compounds content in red cabbage seedlings exposed to copper stress. Ecotoxicology and Environmental Safety 72: 596-602.

[77] Sakihama, Y., Yamasaki, H. (2002): Lipid peroxidation induces by phenolics in cinjunction with aluminium ions. - Biol. Plantarum 45: 249-254.

[78] Schafer, F. Q., Wang, H. P., Kelly, E. E. (2002): Comparing beta-carotene, vitamin E and nitric oxide as membrane antioxidants. - The Journal of Biological Chemistry 383: 671681.

[79] Seregin, I. V., Ivanov, V. B. (2001): Physiological aspects of cadmium and lead toxic effects on higher plants. - Russ. J. Plant Physiol 48: 523-544.

[80] Smeets, K., Cuypers, A., Lambrechts, A., Semane, B., Hoet, P., Van Laere, A., Vangronsveld, J. (2005): Induction of oxidative stress and antioxidative mechanisms in Phaseolus vulgaris after Cd application. - Plant Physiology and Biochemistry 43: 437-444.

[81] Somashekaraiah, B. V., Padmaja, K., Prasad, A. R. K. (1992): Phytotoxicity of cadmium ions on germinating seedlings of mung bean (Phaseolus vulgaris): Involvement of lipid peroxides in chlorphyll degradation. - Physiol Plant. 85: 85-89.

[82] Stobart, A. K., Griffiths, W. T., Ameen-Bukhari, I., Sherwood, R. P. (1985): The effect of $\mathrm{Cd}^{2+}$ on the biosynthesis of chlorophyll in leaves of barley. - Physiol. Plant. 63: 293-298.

[83] Sun, H., Xia, N., Liu, Z., Kong, F., Wang, S. (2019): Removal of copper and cadmium ion from alkaline solution using chitosan-tannin functional paper materials as adsorbents. Chemosphere 236: 124370.

[84] Swain, T., Hillis, W. E. (1959): The phenolics constituants of Prunus domestica-I. The quantitative analysis of phenolics constituents. - Journal of the Science of Food and Agriculture 10: 13.

[85] Tamas, L., Huttova, J., Zigova, Z. (1997): Accumulation of stress protein in intracellular spaces of barley leaves induced by biotic and abiotic factors. - Biol. Plant. 39: 387-394.

[86] Tsai, P. J., McInstosh, J., Pearce, P., Camden, B., Jordan, B. R. (2002): Anthocyanin and antioxidant capacity in Roselle (Hibiscus sabdariffa L.) extract. - Food Res. Int. 35: 351356. 
[87] Vaculík, M., Konlechner, C., Langer, I., Adlassnig, W., Puschenreiter Alexander., Hauser, L. M. T. (2012): Root anatomy and element distribution vary between two Salix caprea isolates with different $\mathrm{Cd}$ accumulation capacities. - Environmental Pollution 163: 117126.

[88] Van Assche, F., Clijsters, H. (1990): Effects of metals on enzyme activity in plants. - Plant Cell Environ. 13: 195-206.

[89] Vazquez, M. D., Poschenrieder, C., Barcelo, J. (1992): Ultrastructural effects and localization of low cadmium concentrations in bean roots. - New Phytologist 120: 215-226.

[90] Verbruggen, N., Hermans, C., Schat, H. (2009): Molecular mechanisms of metal hyperaccumulation in plants. - New Phytol 181: 759-77.

[91] Vezza, M. E., Llanes, A., Travaglia, C., Agostinia, E., Talanoa, M. A. (2018): Arsenic stress effects on root water absorption in soybean plants: physiological and morphological aspects. - Plant Physiology and Biochemistry 123: 8-17.

[92] Volland, S., Bayer, E., Baumgartner, V., Andosch, A., Lutz, C., et al. (2014): Rescue of heavy metal effects on cell physiology of the algal model system Micrasterias by divalent ions. - J. Plant Physiol. 171: 154-163.

[93] Vollmannova, A., Musilova, J., Toth, T., Arvay, J., Bystrick, J., Medvecky, M., Daniel, J. (2014): Phenolic compounds, antioxidant activity and $\mathrm{Cu}, \mathrm{Zn}, \mathrm{Cd}$ and $\mathrm{Pb}$ content in wild and cultivated cranberries and blue berries Intern. - J. Environ. Anal. Chem 94: 1445-1451.

[94] Wang, W., Keturi, P. H. (1990): Comparative seed germination tests using ten plant species for toxicity assessment of metals engraving effluent sample. - Water, Air, Soil Pollut. 52: 369-376.

[95] Xue, Z. C., Gao, H. Y., Zhang, L. T. (2013): Effects of cadmium on growth, photosynthetic rate and chlorophyll content in leaves of soybean seedlings. - Biol Plant 57: 587-590.

[96] Yazdi, M., Kolahi, M., MohajelKazemi, E., GoldsonBarnaby, A. (2019): Study of the contamination rate and change in growth features of lettuce (Lactuca sativa Linn.) in response to cadmium and a survey of its phytochelatin synthase gene. - Ecotoxicology and Environmental Safety 180: 295-308.

[97] Younis, M. E., Tourky, S. M. N., Elsharkawy. E. A. (2018a): Element content, growth and metabolic changes in $\mathrm{Cu}$ - and $\mathrm{Cd}$ stressed Phaseolus vulgaris plants. - Journal of Plant and Environmental Research 3: 9.

[98] Younis, M. E., Tourky, S. M. N., Elsharkawy, S. E. A. (2018b): Symptomatic parameters of oxidative stress and antioxidant defensesystem in Phaseolus vulgaris L. in response to copper or cadmium stress. - South African Journal of Botany 117: 207-214.

[99] Zemanova, V., Pavlík, M., Pavlíkova, D., Kyjakova, P. (2015): Changes in the contents of amino acids and the profile of fatty acids in response to cadmium contamination in spinach. - Plant Soil Environ 61: 285-290.

[100] Zouari, M., Ben Ahmed, Ch., Zorrig, W., Elloumi, N., Rabhi, M., Delmail, D., Ben Rouina, B., Labrousse, P., Ben Abdallaha, F. (2016): Exogenous proline mediates alleviation of cadmium stress by promoting photosynthetic activity, water status and antioxidative enzymes activities of young date palm (Phoenix dactylifera L.). - Ecotoxicology and Environmental Safety 128: 100-108. 